\title{
Correlation between HBsAg Quantitation Assay, Histopathology and Viral - DNA Level in Chronic HBV Patients
}

\author{
Adel A.Mostafa ${ }^{1}$, Mohammed E.El-Shewi ${ }^{1}$, Hatem S. Abd El-Raouf ${ }^{1}$, \\ Waleed A. Elagawy ${ }^{2}$, Mohammed A.El-Rashidy ${ }^{3}$,Hala G.Shouman ${ }^{4}$ \\ ${ }^{1}$ Hepatology, Gastroenterology and Infectious Diseases Department, Faculty of Medicine, Benha \\ University, Egypt. \\ ${ }^{2}$ National Hepatology and Tropical Medicine Research Institute (NHTMRI), Cairo, Egypt. \\ ${ }^{3}$ Pathology Department, Faculty of Medicine, Tanta university, Egypt. \\ ${ }^{4}$ Hepatology Department,Mahalla Teaching Hospital, Al-Mahalla Alkoubra, Egypt.
}

Corresponding Author Hala Gamal Shouman

Mobile:

$+201272228912$

\section{E mail:}

Shouman5555@gmail. com

Key words: HBsAg quantitation, Liver biopsy, $H B V$ DNA levels
Background and study aim : Hepatitis B is a serious and common infectious disease of the liver, affecting millions of people throughout the world. In this regard, Egypt has an intermediate HBV seroprevalence. Quantitation of hepatitis B surface antigen (HBsAg) by automated chemiluminescent micro-particle immunoassay has been proposed to be a surrogate marker. The aim of this study was to evaluate correlation between HBsAg quantitation assay, histopathology and viral-DNA level in chronic hepatitis BeAg negative patients.

Patients and methods: This study carried on $50 \mathrm{HBV}-\mathrm{DNA}$ positive naïve $\mathrm{CHB}$ patients. All the studied patients were $\mathrm{HBeAg}$ negative. HBV DNA was measured by real-time polymerase chain reaction, and serum HBsAg was quantified by electrochemiluminescence assay (Roche Diagnostic). Liver biopsy done to all patients in this study for histopathological grading and staging of hepatic fibrosis by experienced pathologist using METAVER scoring.

Results: A significant correlation between serum HBsAg quantitation level and HBV DNA levels was revealed in all studied $\mathrm{HBeAg}$ negative patients $(\mathrm{r}=0.748, \mathrm{P}=$ $<0.001)$. A significant correlation between serum HBsAg level and fibrosis $(r=0.334$, $\mathrm{P}=0.018$ ). While, there is no significant correlation between serum HBsAg quantitation level and activity by Metaver scoring in all studied patients $(\mathrm{P}>0.05)$.

Conclusion: All the studied patients were tested for assess correlation between $\mathrm{HBsAg}$ quantitation, HBV-DNA level and histopathology grading and staging. There is strong positive correlation between $\mathrm{HBs} A g$ quantation level and HBV-DNA and between HBsAg quantation level and stages of fibrosis. No correlation between HBV DNA levels and histopathology.

and western Europe, 2.0\%- $8.0 \%$ in Mediterranean countries and Japan, and $8.0 \%-20 \%$ in southeast Asia and Sub-Saharan regions [3].

Egypt has an intermediate HBV seroprevalence. $\mathrm{HBV}$ is classified into ten different genotypes (A-J) with different geographic distributions. Genotype D is the most prevalent in the Middle East. Limited data are available about HBV genotyping among Egyptian blood donors, particularly in Upper Egypt [4].

Hepatitis B surface antigen (HBsAg) is considered a milestone in the research history of hepatitis B virus (HBV) and has been used for more than 40 years to confirm HBV infections [5]. 
Recently, the relationship between serum $\mathrm{HBsAg}$ concentrations and HBV-DNA levels in hepatitis B patients who are positive for serum HBsAg and $\mathrm{HBeAg}$ was examined. Serum HBsAg concentration was related to HBV-DNA replication level [6].

The architect HBsAg assay was the first to be approved and is widely used; it is a chemiluminescence microparticle immunoassay (CMIA) in which serum and anti-HBs- coated paramagnetic microparticles are combined [7].

\section{PATIENTS AND METHODS}

\section{Study design :}

Cross-sectional study.

\section{Patients :}

We enrolled in the study 50 naive patients with Chronic hepatitis B virus, consecutively observed at Hepatology department at Mahalla Teaching Hospital in the period between May 2013 to October 2014, fulfilling all criteria detailed below.

\section{Inclusion criteria :}

Patients were included if they had a diagnosis of HBV based on HBsAg, HBeAg, HBV-DNA level, Liver biopsy. Male or female age 18 years or older.

\section{Exclusion criteria :}

- Exclusion of any other case of liver disease other than HBV :

- Co-infection with HCV.

- Hepatic focal lesion or other malignancy.

- Decompensated liver disease.

- Alcoholic liver disease (history of alcohol intake).

- Obesity induced liver disease

- Pregnancy or breast feeding.

All patients were divided into two groups (A\&B) :

- Group A: Including ;(25) patients with Chronic hepatitis B virus subdivided into two sub groups:

- Subgroup (A1) : HBV-DNA <2000 IU/ml with normal ALT.

- Subgroup (A2) : HBV- DNA<2000 IU/ml with persistently elevated ALT (at least for 3 months interval).

- Group B: Including (25) patients with Chronic hepatitis B virus Subdivided into two sub groups :
- Subgroup (B1): HBV-DNA $\geq 2000 \mathrm{IU} / \mathrm{mL}$ with normal ALT.

- Subgroup (B2): HBV-DNA $\geq 2000 \mathrm{IU} / \mathrm{mL}$ with persistently elevated ALT.

All patients were subjected to the following :

1- Full history taking and through clinical examination.

2- Laboratory investigations including :

- Complete blood count (CBC), Liver function tests, HBeAg, HBsAg Quantitation by chemiluminescent microparticle assay and Alpha-feto-protein (IU/ml).

- HBV DNA measurement by real time PCR (Roche): HBV-DNA levels were expressed in IU/ml.

1- Liver biopsy: will be done for histopathological grading and staging of hepatic fibrosis by experienced pathologist using METAVER scoring using special stain (Masson's trichrome stain). Examples of liver biopsy already done for chronic hepatitis B patients in this study reading by histopathologist using hematoxylin and eosin (H\&E) staining and Masson's trichrome stains as shown in (Figs. 1,2).

\section{Statistical analysis :}

The collected data were tabulated and analyzed using SPSS version 16 software (SPSS Inc, Chicago, ILL Company). Categorical data were presented as number and percentages while quantitative data were expressed as mean and standard deviation. Chi square test $\left(\mathrm{X}^{2}\right)$, Spearman's correlation coefficient (rho), ANOVA and Krauskal Wallis test were the used tests of significance. ROC curve was used to determine cutoff values with optimum sensitivity and specificity. The accepted level of significance in this work was stated at $0.05 \quad(\mathrm{P}<0.05$ was considered significant).

\section{RESULTS}

Fifty treatment naive patients with chronic hepatitis B (CHB) (persistent HBsAg positive for 6 months), recruited into the current study and divided into two groups; group (A) included patients with HBV DNA <2000 IU/ml, while group (B) included patients with HBV DNA $\geq 2000 \mathrm{IU} / \mathrm{ml}$.

Group (A) included 18 male and 7 female with their mean age (30.92 \pm 5.64 years), while group (B) included 19 male and 6 female with their 
mean age (29.24 \pm 4 .25years). No significant statistical difference was founded between both groups regarding age and gender as shown in (Table 1).

In group (A) the mean value $\pm \mathrm{SD}$ of $\mathrm{Hb}$ was $(14.12 \pm 1.88)$, WBCs $(5.65 \pm 1.38)$ and for platelets was $(198.72 \pm 61.14)$, while in group (B) the mean value $\pm \mathrm{SD}$ of $\mathrm{Hb}$ was $(13.22+1.55)$, WBCs $(5.89 \pm 1.51)$ and platelets was $(194.44 \pm 59.69)$. No significant difference was found between both groups regarding the previously mentioned parameter, the mean value \pm SD of total bilirubin in all groups was normal in group (A) $(0.84 \pm$ $0.30)$ and in group (B) $(1.00 \pm 0.34 \mathrm{mg} / \mathrm{dl})$. The mean value $\pm \mathrm{SD}$ of prothrombine time was normal in both groups. ALP values were not exceeding upper limit of normal in both groups, the mean value of ALP all groups was not significant. The mean value \pm SD of AFP (alpha fetoprotein) in all groups was normal in group (A) $(2.84 \pm 2.18)$ and in group (B) $(2.50 \pm 1.41)$ as shown in (Table 2).

In both groups (A: HBV-DNA <2000 IU/ml, B: HBV-DNA $\geq 2000 \mathrm{IU} / \mathrm{ml}$ ), there is strong correlation between $\mathrm{HBsAg}$ quantitation and HBV-DNA levels with mean value \pm SD (155.28 $\pm 59.48)$ and $(5359.52 \pm 1754.90)$ respectively with strong statistical significant $(\mathrm{p}=0.001)$ as shown in (Table 3 and Fig.3).

There is no correlation between HBV DNA level among all studied groups which $(<2000 \mathrm{IU} / \mathrm{ml}$ or $\geq 2000 \mathrm{IU} / \mathrm{ml}$ ) with histopathplogy grading and staging by METAVER scoring $(\mathrm{p}=0.467)$ (Table $4)$.

In all studied patients with normal ALT $(\leq 40$ IU/Ml) (group (A1): 13 patients with HBV DNA level $<2000 \mathrm{IU} / \mathrm{ml}$ \& group (B1): 12 patients with HBV DNA level $\geq 2000 \mathrm{IU} / \mathrm{ml}$ ), there is no statistical significant difference regarding histopathology by METAVER scoring ( fibrosis, $\mathrm{p}=$ $0.198 \&$ activity, $\mathrm{p}=0.490$ ) as shown in (Table 5).

In all studied patients with persistently elevated ALT (>40 IU/ml) (group (A2): 12 patients with HBV DNA level <2000 IU/ml \& group (B2): 13 patients with $\mathrm{HBV}$ DNA level $\geq 2000 \mathrm{IU} / \mathrm{ml}$ ), there is no statistical significant difference with histopathology by METAVER scoring (fibrosis, $p=0.192 \&$ activity, $p=0.545$ ) as shown in (Table $6)$.

The study of correlation between HBsAg quantitation and histopathology in all studied groups, showed there is statistical significance between fibrosis and HBsAg quantitation ( $\mathrm{r}=$ $0.334, \mathrm{p}=0.018$ ) and no correlation with activity $(\mathrm{r}=0.017, \mathrm{p}=0.905)$ by metaver scoring (fibrosis and activity) as shown in (Table 7).

In the studied group, a cut-off HBsAg titer of $1730.85 \mathrm{IU} / \mathrm{ml}$ could predict serum HBV DNA levels $\geq 2000 \mathrm{IU} / \mathrm{ml}$ with $100 \%$ sensitivity, $100 \%$ specificity, $\mathrm{P}$ value $<0.001$ and area under the curve $($ AUROC $=1.00)$, as shown in (Table 8 and Fig. 4).

Table (1) : Comparison between patients with HBV DNA level below $2000 \mathrm{IU} / \mathrm{ml} \&$ above 2000 $\mathrm{IU} / \mathrm{ml}$ regarding age and gender

\begin{tabular}{|c|c|c|c|c|c|c|}
\hline \multirow[t]{2}{*}{ Parameter } & \multicolumn{2}{|c|}{$\begin{array}{c}\text { Group (A) } \quad \text { HBV } \\
\text { DNA<2000 IU } / \mathrm{ml} \\
(\mathbf{n}=\mathbf{2 5})\end{array}$} & \multicolumn{2}{|c|}{$\begin{array}{c}\text { Group (B) HBV } \\
\text { DNA } \geq 2000 \mathrm{IU} / \mathrm{ml} \\
(\mathrm{n}=\mathbf{2 5})\end{array}$} & & \multirow[t]{2}{*}{$\mathbf{P}$} \\
\hline & No & $\%$ & No & $\%$ & & \\
\hline $\begin{array}{l}\text { Sex : } \\
\quad \text { Male } \\
\text { Female }\end{array}$ & $\begin{array}{c}18 \\
7\end{array}$ & $\begin{array}{l}72 \% \\
28 \%\end{array}$ & $\begin{array}{c}19 \\
6\end{array}$ & $\begin{array}{l}76 \% \\
24 \%\end{array}$ & $\chi^{2}=0.104$ & 0.747 \\
\hline Age (in years) & \multicolumn{2}{|c|}{$30.92 \pm 5.64$} & \multicolumn{2}{|c|}{$29.24 \pm 4.25$} & $\mathrm{t}=1.189$ & 0.240 \\
\hline BMI (kg/m2) & \multicolumn{2}{|c|}{$30.92 \pm 5.64$} & \multicolumn{2}{|c|}{$29.24 \pm 4.25$} & $\mathrm{t}=1.189$ & 0.240 \\
\hline
\end{tabular}


Table (2) : Comparison between patients with HBV DNA level below $2000 \mathrm{IU} / \mathrm{ml} \&$ above 2000 $\mathrm{IU} / \mathrm{ml}$ regarding complete blood count and liver profile.

\begin{tabular}{|c|c|c|c|c|}
\hline Liver function tests & $\begin{array}{c}\text { Group (A) } \\
\text { HBV DNA<2000 IU } / \mathrm{ml} \\
(\mathrm{n}=\mathbf{2 5})\end{array}$ & $\begin{array}{c}\text { Group (B) } \\
\text { HBVDNA } \geq 2000 \text { IU } / \mathrm{ml} \\
(\mathrm{n}=\mathbf{2 5})\end{array}$ & $\mathbf{t}$ & $\mathbf{P}$ \\
\hline $\mathrm{Hb} \quad(\mathrm{gm} / \mathrm{dl})$ & $14.12 \pm 1.88$ & $13.22 \pm 1.55$ & 1.867 & 0.068 \\
\hline WBCS $\left(\times 10^{3} / \mathrm{mm}^{3}\right)$ & $5.65 \pm 1.38$ & $5.89 \pm 1.51$ & 0.586 & 0.560 \\
\hline Platelets $\left(\mathrm{x} 10^{3} / \mathrm{mm}^{3}\right)$ & $198.72 \pm 61.14$ & $194.44 \pm 59.69$ & 0.250 & 0.803 \\
\hline T. Bilirubin (mg/dl) & $0.84 \pm 0.30$ & $1.01 \pm 0.34$ & 1.773 & 0.083 \\
\hline D. Bilirubin (mg/dl) & $0.38 \pm 0.23$ & $0.49 \pm 0.22$ & 1.838 & 0.072 \\
\hline Albumin $(\mathrm{gm} / \mathrm{dl})$ & $4.32 \pm 0.51$ & $4.11 \pm 0.54$ & 1.407 & 0.166 \\
\hline$\overline{\mathrm{AST}}(\mathrm{IU} / \mathrm{ml})$ & $35.64 \pm 17.18$ & $40.24 \pm 26.55$ & 0.727 & 0.471 \\
\hline Prothrombin time (\%) & $92.83 \pm 9.31$ & $89.16 \pm 10.61$ & 1.300 & 0.200 \\
\hline Alk $\mathrm{Ph}(\mathrm{mg} / \mathrm{dl})$ & $155.16 \pm 51.95$ & $167.32 \pm 58.03$ & 0.781 & 0.439 \\
\hline $\mathrm{AFP}(>20 \mathrm{ng} / \mathrm{ml})$ & $2.84 \pm 2.18$ & $2.50 \pm 1.41$ & 0.656 & 0.516 \\
\hline
\end{tabular}

Table (3) : Correlation between HBV DNA level \&HBsAg quantitation

\begin{tabular}{|l|c|c|c|c|}
\hline \multicolumn{1}{|c|}{ Parameter } & $\begin{array}{c}\text { Group A } \\
\text { HBV DNA<2000 IU/ml } \\
(\mathbf{n = 2 5})\end{array}$ & $\begin{array}{c}\text { Group B } \\
\text { HBV DNA } \mathbf{2 0 0 0} \text { IU/ml } \\
(\mathbf{n = 2 5})\end{array}$ & $\mathbf{t}$ & P \\
\hline $\begin{array}{l}\text { HBsAg Quantitation } \\
(\mathrm{IU} / \mathrm{ml})\end{array}$ & $155.28 \pm 59.48$ & $5359.52 \pm 1754.90$ & 14.819 & $<0.001^{*}$ \\
\hline
\end{tabular}

Table (4) : Comparison between patients with HBV DNA level below $2000 \mathrm{IU} / \mathrm{ml}$ and above 2000 $\mathrm{IU} / \mathrm{ml}$ regarding Histopathology

\begin{tabular}{|c|c|c|c|c|}
\hline Parameter & $\begin{array}{c}\text { Group A } \\
\text { HBV DNA<2000 IU } / \mathrm{ml} \\
(\mathbf{n}=\mathbf{2 5}) \\
\end{array}$ & $\begin{array}{c}\text { Group B } \\
\text { HBV DNA } \geq 2000 \mathrm{IU} / \mathrm{ml} \\
(\mathbf{n}=\mathbf{2 5}) \\
\end{array}$ & $\mathbf{t}$ & $\mathbf{P}$ \\
\hline $\begin{array}{c}\text { Histopathology } \\
\text { Metaver fibrosis } \\
\text { (F0) } \\
\text { (F1) } \\
\text { (F2) } \\
\text { (F3) } \\
\text { (F4) }\end{array}$ & $\begin{array}{c}0(0 \%) \\
19(76 \%) \\
4(16 \%) \\
2(8 \%) \\
0(0 \%)\end{array}$ & $\begin{array}{c}0(0 \%) \\
12(48 \%) \\
10(40 \%) \\
3(12 \%) \\
0(0 \%)\end{array}$ & $\begin{array}{c}\chi^{2}= \\
4.352\end{array}$ & 0.113 \\
\hline $\begin{array}{c}\text { Histopathology } \\
\text { Metaver activity } \\
\text { (A0) } \\
\text { (A1) } \\
\text { (A2) } \\
\text { (A3) }\end{array}$ & $\begin{array}{c}0(0 \%) \\
21(84 \%) \\
3(12 \%) \\
1(4 \%)\end{array}$ & $\begin{array}{c}0(0 \%) \\
20(80 \%) \\
5(20 \%) \\
0(0 \%)\end{array}$ & $\begin{array}{c}\chi 2= \\
1.524\end{array}$ & 0.467 \\
\hline
\end{tabular}


Table (5) : Comparison between the studied groups regarding HBV DNA level \& Histopathology with normal ALT $(\leq 40 \mathrm{IU} / \mathrm{ml})$

\begin{tabular}{|c|c|c|c|c|}
\hline Parameter & $\begin{array}{c}\text { Group A } \\
\text { HBV-DNA<2000Iu/ml } \\
(\mathbf{n = 1 3})\end{array}$ & $\begin{array}{c}\text { Group B } \\
\text { HBV-DNA } \mathbf{2 0 0 0 I u} / \mathbf{m l} \\
(\mathbf{n = 1 2})\end{array}$ & $\chi \mathbf{2}$ & $\mathbf{P}$ \\
\hline $\begin{array}{c}\text { Histopathology: } \\
\text { Metaver fibrosi }\end{array}$ & & & & \\
(F0) & $0(0 \%)$ & $0(0 \%)$ & & \\
(F1) & $11(84.6 \%)$ & $8(66.7 \%)$ & 3.239 & 0.198 \\
(F2) & $1(7.7 \%)$ & $4(33.3 \%)$ & & \\
(F3) & $1(7.7 \%)$ & $0(0 \%)$ & & \\
(F4) & $0(0 \%)$ & $0(0 \%)$ & & \\
\hline Histopathology: & & $0(0 \%)$ & & \\
Metaver Activity: & $0(0 \%)$ & $10(83.3 \%)$ & 0.476 & 0.490 \\
(A0) & $12(92.3 \%)$ & $2(16 \%)$ & & \\
(A1) & $1(7.7 \%)$ & $0(0 \%)$ & & \\
(A2) & $0(0 \%)$ & &
\end{tabular}

Table (6) : Comparison between the studied groups regarding HBV DNA level \& Histopathology with elevated ALT ( $>40 \mathrm{IU} / \mathrm{ml})$

\begin{tabular}{|c|c|c|c|c|}
\hline Parameter & $\begin{array}{c}\text { Group A } \\
\text { HBV-DNA<2000Iu/ml } \\
(\mathbf{n = 1 2})\end{array}$ & $\begin{array}{c}\text { Group B } \\
\text { HBV-DNA } \geq \mathbf{2 0 0 0 I u} / \mathbf{m l} \\
(\mathbf{n}=\mathbf{1 3})\end{array}$ & $\chi^{\mathbf{2}}$ & $\mathbf{P}$ \\
\hline $\begin{array}{c}\text { Histopathology: } \\
\text { METAVER }\end{array}$ & & & & \\
(F0) & $0(0 \%)$ & $0(0 \%)$ & & \\
(F1) & $8(66.7 \%)$ & $4(30.8 \%)$ & 3.299 & 0.192 \\
(F2) & $3(25 \%)$ & $6(46.2 \%)$ & & \\
(F3) & $1(8.3 \%)$ & $3(23.1 \%)$ & & \\
(F4) & $0(0 \%)$ & $0(0 \%)$ & & \\
\hline Histopathology: & & $0(0 \%)$ & & \\
Metaver activity & $0(0 \%)$ & $10(76.9 \%)$ & 1.215 & 0.545 \\
(A0) & $9(75 \%)$ & $3(23.1 \%)$ & & \\
(A1) & $2(16.7 \%)$ & $0(0 \%)$ & & \\
(A2) & $1(8.3 \%)$ & & \\
(A3) & &
\end{tabular}

Table (7): Comparison between Hepatitis B surface quantitation antigen and Histopathology in all studied groups

\begin{tabular}{|l|c|c|}
\hline \multirow{2}{*}{ Variables } & \multicolumn{2}{|c|}{ Hepatitis B surface antigen quantitation } \\
\cline { 2 - 3 } & $\mathbf{r}$ & $\mathbf{p}$ \\
\hline Activity & 0.017 & 0.905 \\
\hline Fibrosis & 0.334 & $0.018^{*}$ \\
\hline
\end{tabular}

Table (8) : ROC curve for Hepatitis B surface antigen for detection of level of Hepatitis B DNA-PCR $\geq 2000 \mathrm{IU} / \mathrm{ml}$

\begin{tabular}{|l|c|}
\hline \multicolumn{1}{|c|}{ Variable } & Results \\
\hline Area under the curve & 1.00 \\
\hline P value & 0.001 \\
\hline Cut off point & 1730.85 \\
\hline Sensitivity & $100 \%$ \\
\hline Specificity & $100 \%$ \\
\hline
\end{tabular}


A

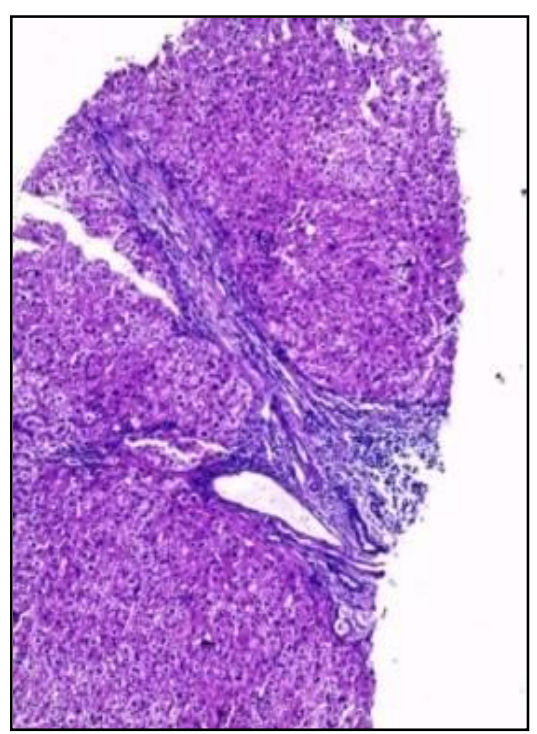

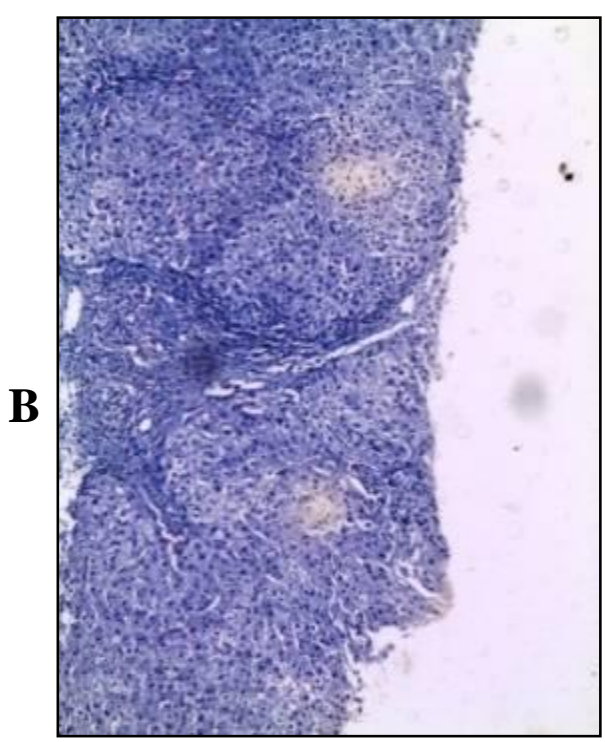

Fig. (1): Liver biopsy of chronic hepatitis B patient showing expansion of portal tract with fibrous septae (A1F1) using (H\&E/100x) as in (A) \& using masson's trichrome stain asin (B)
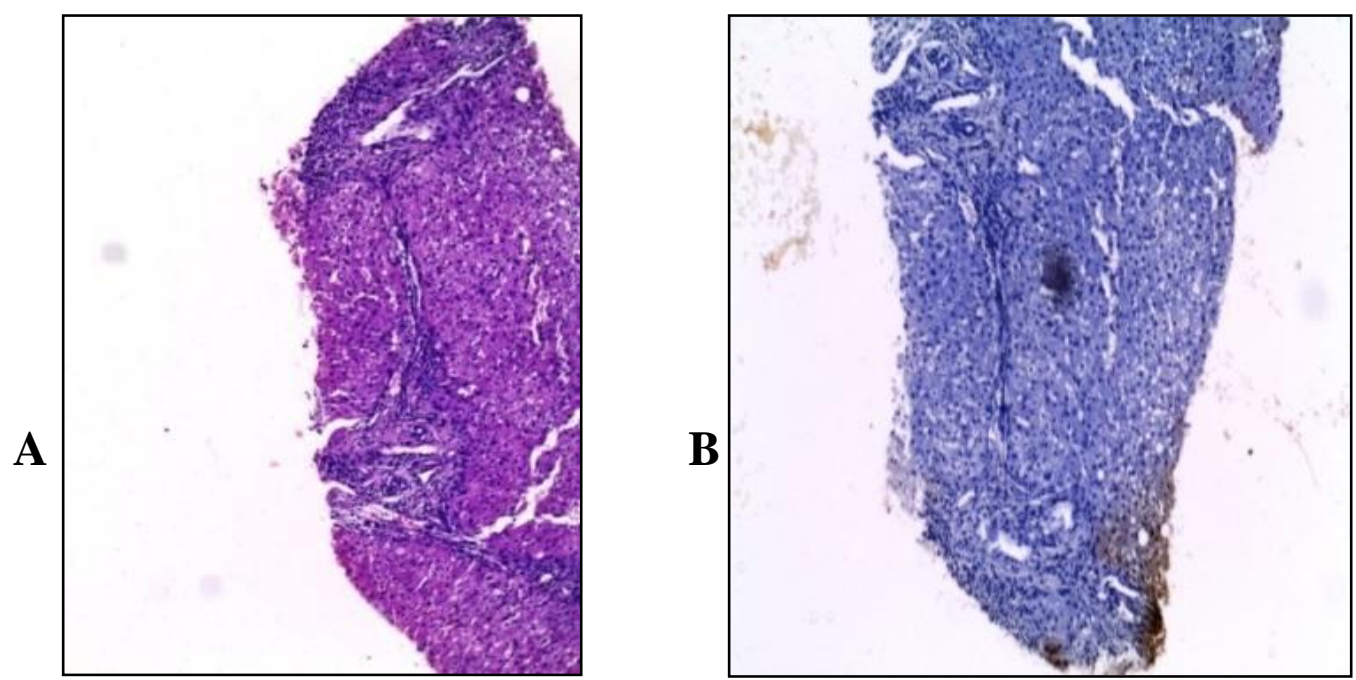

Fig. (2) : Liver biopsy of chronic hepatitis B patient showing bridging fibrous tissues (A2F2) using $(\mathrm{H} \& \mathrm{E} / 100 \mathrm{x})$ as in (A) \& using masson's trichrome stain (100x) stain as in (B) 


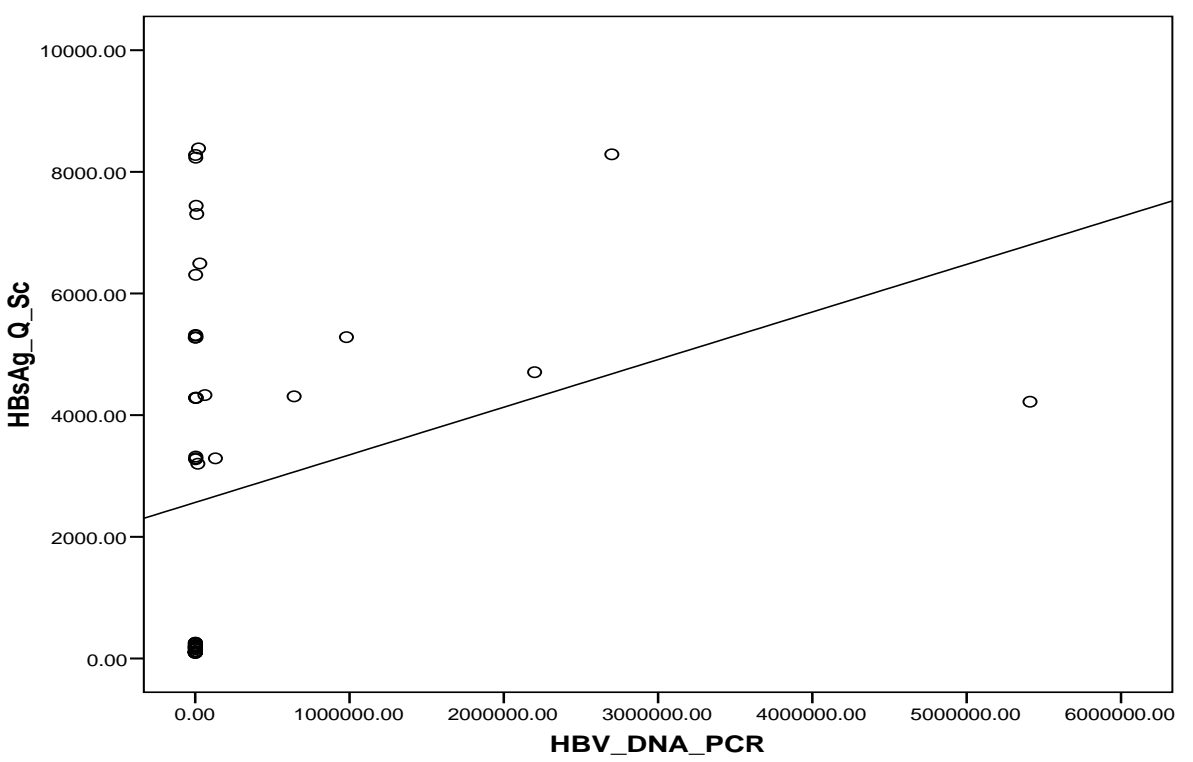

Fig. (3): Pearson correlation between HBV-DNA level and HBsAg Quantitation in all studied patients.

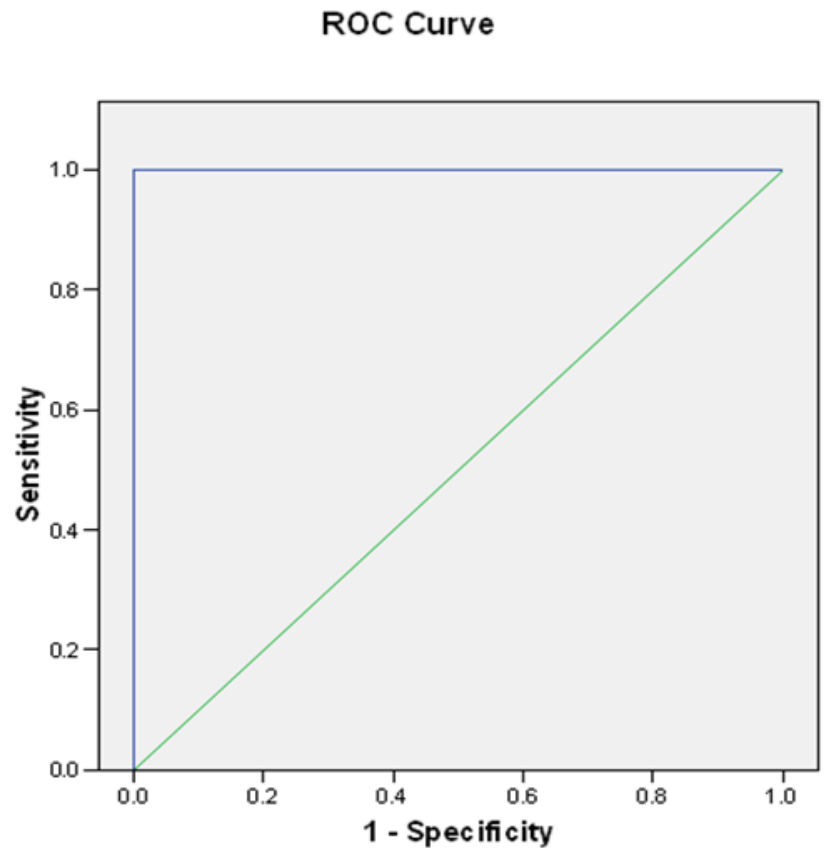

Fig. (4): The $\mathrm{ROC}$ (receiver operating characteristic) curve was for performance of HBsAg quantitation

\section{DISCUSSION}

The hepatitis B surface antigen ( $\mathrm{HBsAg}$ ) was identified more than 40 years ago. Detection of $\mathrm{HBsAg}$ in serum is still the hallmark of $\mathrm{HBV}$ infection and the cornerstone for the diagnosis of hepatitis B virus (HBV) infection. Over the years, HBsAg has been shown to be a reliable marker to predict clinical outcome [8].
HBsAg is secreted into the circulation as tubular forms or spherical particles by $\mathrm{HBV}$-infected hepatocytes. Patients with chronic hepatitis B (CHB) usually express different levels of HBsAg when assayed by immunohistochemistry [9].

Recently, there has been an increasing focus on quantitative $\mathrm{HBs} \mathrm{Ag}$ (qHBsAg) and its use in the management of patients with CHB. The interest in $\mathrm{qHBs} A \mathrm{~g}$ started with the possible observation 
of its correlation with intra-hepatic $\mathrm{HBV}$ covalently closed circular (ccc) DNA, a true marker of HBV replication [10].

The quantitation of viral load is a routinely performed molecular test in clinical laboratories. The real-time PCR-based commercial assays for HBV DNA quantitation used in clinical practice have been available worldwide for several years [11].

The gold standard tool in assessing the stage of liver fibrosis is the histological evaluation of a liver biopsy. However, the procedure carries a moderate risk of complications, including bleeding and a small risk of death [12].

This study aimed to evaluate correlation between HBsAg quantitation assay, histopathology and HBV- DNA level in chronic HBV patients.

This study involved 50 patients with chronic hepatitis $\mathrm{B} ; 37$ of them were males $(74 \%)$ and 13 were females (26\%). This finding goes in line with El- Zayadi et al. who reported that (46 male and 6 female) with a median age of 37.5 years in evaluation of Egyptian Chronic Hepatitis B Patients and HBeAg-negative variant accounts for more than $80 \%$ of CHB in Egypt [13].

In this study there is no correlation between complete blood count and liver profile (serum bilirubin, serum albumin, AST, alkaline phosphatase, $\alpha$-fetoprotein and prothrombine time) with HBV-DNA levels, this is in agreement with Koyuncure, who concluded that there was no correlation between HBV-DNA levels and biochemical tests [14].

In this study there is strong correlation among the studied groups between HBsAg quantitation and HBV-DNA levels $(\mathrm{p}=0.001)$, this finding is supported by other studies. For example, in the study by Alghamdi et al., study had found statistically significant positive correlation between HBsAg titers and HBV DNA levels [15].

In addition Primadharsini and Wibawa [16] had showed significant and strong correlation between quantitative HBsAg and HBV-DNA. Furthermore the study by Hong et al.[17] who concluded that in the 183 patients in whom serum HBsAg levels were quantified, there was a positive correlation between HBsAg quantitation and HBV DNA levels (0.0001).

Also, Karagoz et al. had concluded that serum HBsAg titers correlate with HBV DNA in treatment-naïve patients [18].
Another study by Ozgur et al. had reported that there was statistically significant correlation determined between HBsAg level and HBV DNA ( $\mathrm{P}=0.0001)$ [19].

Recently this also, had concluded by Gupta et al, who found that weak but significant correlation between quantitative HBsAg and HBV-DNA in all the groups $(\mathrm{p}<0.01)$ [9].

Moreover, Li et al. had founded a significant positive correlation ( $\mathrm{r}=0.642$, $\mathrm{P}$ less than 0.0001 ) between HBsAg titre and HBV DNA load [20].

In contrast with Ganiji et al. study who revealed that by electrochemiluminescence assay of HBsAg levels has no significant correlation with HBV DNA levels in chronic hepatitis $B$ $(\mathrm{p}=0.606)[21]$.

In addition, Mukherjee et al had founded that the correlation between serum HBV- DNA and serum concentration of HBsAg was not evident [22].

Result in this study revealed that, there is no significant correlation between HBV-DNA levels and histopathology (fibrosis and activity) by Metaver score among the studied groups ( $\mathrm{p}=0.467 \& \mathrm{p}=0.113$ respectively). This finding is supported by other studies. For example, in the study by Shafaei et al. who revealed that there was no significant difference with fibrosis stage regarding different viral loads [23].

In addition Xie et al. had observed that there is negative correlation between HBV DNA levels and significant fibrosis [24]. Furthermore Harkisoen et al. had revealed that there was no significant correlation between HBV DNA levels and liver fibrosis [25].

In contrast to this study; Bai et al. had found that positive correlation between the severity of hepatic inflammation and fibrosis and serum HBV DNA level $(\mathrm{P}<0.001) \quad$ [26]. This association was found by Praneenararat et al. who concluded that serum HBV-DNA level >5.5 $\log \mathrm{IU} / \mathrm{ml}$ should predict a significant liver fibrosis in treatment naïve chronic hepatitis B that had indicated for liver biopsy [27].

In this study, there is statistically significant positive correlation among all studied groups between HBsAg quantitation and fibrosis $(\mathrm{P}=$ 0.018). This is in agreement with Cheng et al. who had concluded that the correlation between advanced liver fibrosis and HBsAg level was a significant [28]. 
In addition to Zhong et al. who had concluded that the level of $\mathrm{HBsAg}$ of Chinese chronic hepatitis B patients correlate with liver inflammation and fibrosis [29].

Furthermore, Hong et al. had found that there was a positive correlation between HBsAg levels and stage of fibrosis. Also, Marcellin et al. had concluded that there was significant correlation between HBsAg levels and advanced fibrosis [30].

In this study, the validity of $\mathrm{HBsAg}$ titer in detecting cases with elevated HBV DNA level $(\geq$ $2000 \mathrm{IU} / \mathrm{ml}$ ) with $\mathrm{HBs}$ Ag level at cut off point $<1730.85$ (IU/ml) with sensitivity, specificity (100\% \&100\%, respectively) in all studied groups with $\mathrm{P}$ value $<0.001$ and Area under the curve $($ AUROC $)=1$.

This study concluded that, there is strong significant correlation between HBsAg quantitation and HBV DNA levels, also there is correlation between HBsAg quantitation and fibrosis in contrast to no correlation between HBV DNA levels and histopathology ..

Funding: None.

Conflicts of interest: None.

Ethical approval: Approved.

\section{REFERENCES}

1. European Association for the Study of the Liver: EASL clinical practice guidelines: management of chronic hepatitis B. Journal of Hepatology 2012; 57: 167-185.

2. Seto W-K, Wong DK-H, Fung J, Ip PPC, Yuen JC-H: High Hepatitis B Surface Antigen Levels Predict Insignificant Fibrosis. Journal Pone 2012; 7(8): e43087.

3. Sagnelli E, Sagnelli C, Pisaturo M, Maceraand M, Coppola N. Epidemiology of acute and chronic hepatitis B and delta over the last 5 decades in Italy. World Journal of Gastroenterology 2014; 20(24):7635-7643.

4. Habil F.E., Mahdi W.K.M., Abdelwahab S.F. Hepatitis B virus genotype Dpredominates HBsAg-positive egyptian blood donors and is mainly associated with anegative $\mathrm{HBeAg}$ serostatus. Intervirology. 2013;56(5):278-83.

5. Zhang YM, Yang YD, Jia HY. HBsAg levels in HBeAg-positive chronic hepatitis B patients with different immune conditions. World Jornal of Gastroenterology 2014; 20 (15): 4407-4413.
6. Ganji A, Esmaeilzadeh A, Ghafar-zadegan K. Correlation between HBsAg quantitative assay results and HBV DNA levels in chronic HBV. International Monthly Journal in the Field of Hepatitis 2011; 11 (5): 342-345.

7. Schillie S,Murphy TV, Sawyer M,Ly K, Hughes E,Jiles $\mathrm{R}$ et al. Centers for disease control and prevention Guidance for Evaluating Health-Care Personnel for Hepatitis B Virus Protection and for Administering Postexposure Management . MMWR Recomm Rep 2013; 62 (10): 1-19.

8. Martinot-Peignoux M, Lapalus M, Asselah TAD, Marcellin P . HBsAg quantification: useful for monitoring natural history and treatment outcome. Liver International Journal 2014; 34 (Suppl 1): 97-107.

9. Gupta E, Pandey P, Kumar K. Correlation between two chemiluminescence based assays for quantification of hepatitis B surface antigen in patients with chronic hepatitis B infection Indian Journal of Medical Microbiology 2015 ; 33 (1): 96-100.

10. Hong MZ, Huang WQ, Min F, Xu JC, Lin Z. Enhanced HBsAg Synthesis Correlates with Increased Severity of Fibrosis in Chronic Hepatitis B Patients. PLoS One Journal of Hepatology 2014 ; 9 (1): e87344.

11. Qiu N, Li R, Yu JG, Yang W, Zhang W. Comparison of Abbott and Da-an real-time PCR for quantitating serum HBV DNA. World Journal of Gastroenterology 2014; 20 (33): 11762-11769.

12. Omran MM, Farid K, Emran TM, Attallah AA.Fibro $\alpha$-score as a simple and useful noninvasive test for predicting significant liver fibrosis in chronic hepatitis C patients. Arab Journal of Gastroenterology 2011; 12: 74-79.

13. El-Zayadi A, Badran HM, Saied A, Shawky S, Attia M, Zalata K. Evaluation of Liver Biopsy in Egyptian HBeAg-Negative Chronic Hepatitis B Patients at Initial Presentation Implications for Therapy. The American Journal of Gastroenterology 2009; 104: 906 - 911.

14. Koyuncuer A. Associations between $\mathrm{HBeAg}$ status, HBV-DNA, ALT level and liver histopathology in patients with chronic hepatitis B. Science Journal of Clinical Medicine 2014; 3 (6): 117-123.

15. Alghamdi A, Aref N, El-Hazmi M, Al-Hamoudi W, Alswat K. Correlation between hepatitis B surface antigen titers and HBV DNA levels. Saudi Journal of Gastroenterology 2013; 19 (6): 252257. 
16. Primadharsini PP,Wibawa DN.Correlation between quantitative HbsAg and HBV-DNA in chronic hepatitis $\mathrm{B}$ infection. The Indonesian Journal of Gastroenterology, Hepatology and Digestive Endoscopy 2013; 14, 1.

17. Hong MZ, Huang WQ, Min F, Xu JC, Lin Z. Enhanced HBsAg Synthesis Correlates with Increased Severity of Fibrosis in Chronic Hepatitis B Patients. PLoS One Journal of Hepatology 2014; 9 (1): e87344.

18. Karagoz E, Tanoglu A , Turhan V. Correlation between Hepatitis B Surface Antigen Titers and HBV DNA Levels. Saudi Journal of Gastroenterology 2014; 20 (1):74.

19. Ozgur G, Sener B,Liker E,Fazilet D. Relation between serum quantitative HBsAg,ALT and HBV DNAlevels an HBeAg negative chronic HBV infection. Turk Journal Gastroenterol 2014; 25(1):142-6.

20. Li G, Wang J, Bao Y, Zhenq L, Ge K. Clinical significance of serum HBsAg levels, HBsAg/ HBV DNA ratio, and association with liver inflammation activity in $\mathrm{HBeAg}$-positive chronic hepatitis B.Chinese Journal of Hepatology 2015; 23(1):40-45.

21. Ganji A, Esmaeilzadeh A, Ghafar-zadegan K. Correlation between HBsAg quantitative assay results and HBV DNA levels in chronic HBV. International Monthly Journal in the Field of Hepatitis 2011; 11 (5): 342-345.

22. Mukherjee R. M, Arava J, Reddy PB. Role of hepatitis B virus surface antigen quantitation in $\mathrm{E}$ antigen negative chronic hepatitis infection. Global Journal of Science 2013; 13-3.

23. Shafaei S, Amiri SS, Hajiahmadi M, Zavareh M.S. Histological grading and staging of liver and its relation to viral loads in chronic hepatitis B.Caspian journal of Internal Medicine 2013; 4(3):681-685.

24. Xie Q, Hu X, Zhang Y, Jiang X. Decreasing hepatitis B viral load is associated with a risk of significant liver fibrosis in hepatitis B e antigen positive chronic hepatitis B. Journal of Medical Virology 2014; 86(11):1824-1837.
25. Harkisoen S, Arends J.E, van den Hoek J.A.R. , Whelan J, van Erpecum K.J. Historic and current hepatitis B viral DNA and quantitative HBsAg level are not associated with cirrhosis in nonAsian women with chronic hepatitis B. International Journal of Infectious Diseases 2014; 29(12):133-138.

26. Bai H, Liu H,Chen X,Dou X. Influence of Age and HBeAg Status on the Correlation Between HBV DNA and Hepatic Inflammation and Fibrosis in Chronic Hepatitis B Patients. Digestive diseases and sciences 2012; 58 (5): 1355-1362.

27. Praneenararat S, Chamroonkul N, Sripongpun P, Kanngurn S, Jarumanokul R. HBsAg levels did not predict significant liver histology in patients with $\mathrm{HBeAg}$ negative chronic hepatitis B. Thia Journal of Gastroenterology 2014; 15 (2): 69-77.

28. Cheng PN, Tsai HW, Chiu YC, Ho CH, Wu IC . Clinical significance of serum HBsAg levels and association with liver histology in $\mathrm{HBeAg}$ positive chronic hepatitis B. Journal of Clinical Virology 2013;57(4):323-30.

29. Zhong LH, Jiang YM, Lou GQ, Yu XL. The relation between serum HBsAg levels and liver inflammation and fibrosis in patients with chronic hepatitis B. Chinese Journal of Experimental and Clinical Virology 2013; 27(2): 92-94.

30. Marcellin P, Martinot-Peignoux M, Asselah T, Batria R. Serum Levels of Hepatitis B Surface Antigen Predict Severity of Fibrosis in Patients with Chronic Hepatitis B. Clinical Gastroenterology and Hepatology journal 2013; 58:1089-1095.

Peer reviewer: Rashed Hasan, Professor of Tropical Medicine and Hepatogastroenterology, Faculty of Medicine, Zagazig University, Egypt. Editor:Tarik Zaher , Professor of Tropical Medicine and Hepatogastroenterology, Faculty of Medicine, Zagazig University, Egypt. 